Boston University School of Law Scholarly Commons at Boston University School of Law

Faculty Scholarship

7-15-2018

\title{
The Policy Challenge of Artificial Intelligence
}

James Bessen

Boston University School of Law

Follow this and additional works at: https://scholarship.law.bu.edu/faculty_scholarship

Part of the Antitrust and Trade Regulation Commons, Law and Economics Commons, and the Science and Technology Law Commons

\section{Recommended Citation}

James Bessen, The Policy Challenge of Artificial Intelligence, Boston University School of Law Law \& Economics Paper Series (2018). Available at: https://scholarship.law.bu.edu/faculty_scholarship/449

This Article is brought to you for free and open access by Scholarly Commons at Boston University School of Law. It has been accepted for inclusion in Faculty Scholarship by an authorized administrator of 


\title{
The Policy Challenge of ARTificial INTELLIGENCE
}

\author{
Boston University School of Law \\ Law \& Economics Research Paper No. 18-16
}

July 2018

James Bessen

Boston University School of Law

Previously published in the June 2018

CPI Antitrust Chronicle 
The Policy Challenge of Artificial Intelligence

James Bessen

The new technologies of the "Fourth Industrial Revolution" promise to bring dramatic social and economic changes. Already, machines can drive cars, they can outperform humans at analyzing X-rays and playing games, and a host of new materials and 3D printing are changing manufacturing. Commentators have raised concerns that these new technologies may destroy jobs or reduce wages, perhaps creating social and political upheaval. Also, these new technologies will surely bring challenges to intellectual property (IP) and antitrust regulation, including concerns about the ownership of Big Data and privacy, the ability of anyone with a 3D printer to become a manufacturer by downloading designs off the Internet and more.

Yet to a great degree, the role of IP and antitrust in the new era will be a continuation of their role in today's technologically advanced sectors. And here the news is not all good, particularly in regard to information technology (IT). Across all major sectors of the economy, large firms are becoming more dominant in their markets and IT is a major reason for this. Leading firms in each industry are able to use proprietary IT systems to gain market share at the expense of smaller rivals. This might not seem like bad news, especially for the shareholders of large firms, but it is evidence of a slowdown in the spread of technical knowledge throughout the economy. The result is not only rising industry concentration, but also slower average productivity growth and growing wage inequality.

Perhaps the biggest challenge that new information technologies may pose to IP/antitrust policy is their effect on the diffusion of knowledge. The "Progress of Science 
and the Useful Arts" depends both on the development of new innovations and on the spread of related knowledge so that new techniques can be used widely. Both IP law and antitrust law pay heed to balancing these concerns, balancing innovation incentives against the need for disclosure and competition, balancing concerns about market power against considerations of efficiency.

The current trend of rising industry concentration implies that this balance has been lost with regard to information technology and policies are not sufficiently encouraging the diffusion of knowledge. While technical factors such as economies of scale and network effects surely contribute to the growing dominance of large firms, the policy challenge is to offset this trend. To date, IP and antitrust policy have not been doing enough and they might be making things worse. Moreover, emerging information technologies, most importantly machine learning, may well exacerbate these problems.

\section{Rising industry concentration}

Industry concentration has been rising across sectors in the US since the 1980s. Autor et al. (2017) find that from 1982 to 2012 the share of shipments made by the top four firms in four-digit industries grew $4.5 \%$ in manufacturing industries, $4.4 \%$ in service industries, $15.0 \%$ in retail industries, and $2.1 \%$ in the wholesale sector. ${ }^{1}$ What is driving this change and what is its significance?

Some see rising concentration as a sign of decreasing competition that might lead to higher prices, less innovation, and greater wage inequality. ${ }^{2}$ This view is bolstered by evidence of a concomitant rise in profit margins and markups (Rognlie 2015, Barkai 2016, de

\footnotetext{
${ }^{1}$ See also White and Yang (2017) on trends in aggregate concentration.

2 The Economist, “Too much of a good thing,” March 26, 2016.
} 
Loecker and Eeckhout 2017). Figure 1 shows the recent rise in profits. The black line, also drawn from the National Accounts, represents the ratio of the net operating surplus to gross value added for the corporate sector (nonfinancial and financial). The gray line is the ratio of aggregate operating income after depreciation to revenues for firms publicly listed in the US. Rising profit margins might also be a sign of declining competition.

However, that is not necessarily the case. The interpretation depends on what is causing the rise in industry concentration and firm profit margins. Declining competition is one possibility. Grullon et al. (2016) attribute the rise in industry concentration partly to lax antitrust enforcement of mergers and acquisitions. Gutierrez and Philippon (2017) suggest that growing federal regulation might be creating entry barriers, also reducing competition. If these views are right, then perhaps antitrust enforcement needs to be strengthened or other policy changes made to increase competition.

\section{The productivity gap}

But another possibility is that some firms — but not all—benefit significantly from new technologies. That is, top firms may be growing larger and taking greater market share not because of mergers or cartelization, but because they are more productive and are thus able to lower prices or provide greater quality products and services.

Concerns about rising industry concentration and its effects are not new. Starting with Demsetz (1973), economists recognized that high industry concentration might be a sign of superior performance rather than an indicator of insufficient competition. In the 1970s, Peltzman (1977) documented rising concentration in manufacturing industries, but he argued that these increases were largely the result of technological progress, and therefore antitrust authorities need not be concerned. Scherer (1979) attributed the increases largely to 
economies of scale, arguing that antitrust authorities could distinguish genuine scale economies from attempts to limit competition through acquisition where they could perform their valuable role.

Something similar seems to be happening today. Thanks to new technology, top firms earn higher profits and realize larger market share, hence higher concentration. In a careful analysis, Autor et al. (2017) find strong evidence that market share is being reallocated to "superstar" firms that outperform rivals; they are more productive hence they grow faster. In this case, the superior performance of these leading firms might result from greater innovation and might produce greater social benefit. But what might cause the top firms to grow faster? The authors speculate that the underlying cause might actually be greater competition caused by globalization or better comparative price information made available by the Internet or other technology. In their model, greater competition, captured by an increase in the elasticity of demand, increases the market advantage of more productive firms.

Yet greater competition does not seem to entirely explain the reallocation. For one thing, if greater competition were driving the rise in industry concentration, we might expect this effect to be greatest in those industries most affected by global trade. The evidence, however, suggests that industry concentration is increasing across almost all sectors.

But there is another factor that seems to be affecting the market share of superstar firms. Several studies point to a growing divergence in firm productivity within industries; the gap between the top performing firms and the rest is growing (Andrews et al. 2016; Berlingieri et al. 2017, Decker et al. 2017). Thus, resources might also be shifting to top firms as their relative productivity grows. 
Figure 2 shows the annual growth rate of revenues per employee for publicly listed firms in the US breaking out the performance of the 50 largest firms from the rest. From 1980 through 1999, the productivity of the largest firms grew at about the same rate as the productivity of the rest of the firms. But from 2000 through 2014, the productivity of the largest firms grew substantially faster. This meant that the market shares of the largest firms increased substantially because revenues per employee increased.

\section{IT and large firms}

But what is driving this productivity gap? New evidence is emerging that it is substantially driven by new information technology systems. This might seem counterintuitive because many basic components of information technology—low cost personal computers, pre-packaged software, networking hardware, etc.- are available offthe-shelf to both large firms and small firms. Indeed, for this very reason it has been argued that IT "levels the playing field."

But there are different types of IT. While putting word processors on desks is not likely to generate competitive advantage, that is not the case with proprietary mission-critical IT systems. Firms have heterogeneous abilities to develop cutting edge IT systems because they have managers or software developers with different abilities. Also, software development typically requires large upfront fixed costs but has low marginal costs. Because of this cost structure, IT systems can have large economies of scale. In addition, some IT systems might exploit network effects. For example, Hughes and Mester (2013) see both fixed IT development costs and network effects in payment systems contributing to substantial scale economies in banking. Similarly, IT systems have helped Walmart achieve more efficient logistics, higher turnover of inventory, and greater product variety at lower 
cost. And the huge investments in IT systems needed to design and manufacture jumbo jets has put this market beyond the reach of all but Boeing and Airbus.

These proprietary IT systems used by large banks and Walmart and Boeing are crucially different from the general use of IT because they provide competitive advantage. By contrast, for example, many restaurants use off-the-shelf point of sale systems. These provide improved service but, because these systems are also widely available to competitors, they are not likely to provide a substantial competitive advantage that allows a restaurant to gain substantial market share. But firms with successful proprietary systems might well grow faster than other firms in the same industry. Proprietary IT thus provides a specific mechanism that can help explain the reallocation to more productive firms, rising industry concentration, also growing productivity dispersion between firms within industries, and growing profit margins.

When the scale economies and network effects of proprietary systems are particularly strong, they may give rise to "winner-take-all" or "winner-take-most" markets. For example, IT platforms enable Amazon to dominate the market for online retail. But that does not appear to be the situation in most industries. While industry concentration has been rising across all major sectors, most industries have cannot be accurately characterized as "winnertake-most," for example, the top four firms capture the majority of revenues in just over a quarter of six-digit NAICS industries.

Nevertheless, rising industry concentration is a general concern and empirical evidence finds a major role of IT in this trend. There is a large literature on why productivity varies substantially between firms in the same industries. Some research specifically finds that the growth in the dispersion of productivity and wages is at least partly accounted for by 
information technology (Abowd et al. 2007; Doms, Dunne, and Troske 1997; Dunne et al. 2004).

A key question is why information technology should be associated with widely disparate levels of productivity. While the hardware components of IT systems are usually generic commodities, the systems themselves typically involve proprietary software and complementary human or organizational capital. There is a significant literature that identifies IT-related differences in productivity arising from complementary skills, managerial practices, and business models that are themselves unevenly distributed. Skills and managerial knowledge needed to use major new technologies have often been unevenly distributed initially because much must be learned through experience, which tends to differ substantially from firm to firm.

Recent empirical research makes three major findings:

1. Industry use of IT systems is associated with higher industry concentration ratios (shares of sales to the top firms) and with more rapid growth in concentration ratios (Bessen 2018). The effect is large-it accounts for most of the observed rise in concentration ratios. Moreover, an instrumental variable analysis provides evidence that the relationship is causal, that is, investments in IT systems caused the increase in industry concentration.

2. IT systems use is strongly associated with the growth in operating profit margins of publicly listed firms in the US from 2000 to 2014 (Bessen 2018). Relatedly, Calligaris, Criscuolo, and Marcolin find that digitization is associated with rising firm markups (the premium of prices over marginal cost) for firms in OECD nations from 2001 through 2014. Bessen finds that IT systems account for most of the increase in operating margins over this period and again, the relationship appears to be causal.

3. It's the top firms that are benefitting from these trends. Industry use of IT systems is associated with larger revenues per establishment and higher labor 
productivity among the top four firms within each industry, both in absolute terms and relative to other firms in the industry.

In contrast, the empirical evidence does not support the hypothesis that rising industry concentration and rising operating margins result mainly from less competitive industry structures. Industry measures of merger and acquisition activity and of entry are not associated with increases in industry concentration. And once IT and intangibles are taken into account, the residual trend in operating margins is not positive, weighing against a general decline in competition as the source of the increase in margins.

Thus, the evidence points to technology and, in particular, information technology as a major driver of rising industry concentration. The top firms within industries are able to harness the technology to become more productive and to grow faster. In this way they come to increase their dominance over markets and to raise their profits. Overall, the analysis here suggests that the recent overall rise in industry concentration is not mainly the result of anticompetitive activity that should worry antitrust authorities.

\section{The policy challenge}

Of course, this is not all bad news. IT systems appear to bring real economic benefits_-both to consumers and shareholders - in terms of greater output per worker even it does raise industry concentration. While there may be other reasons to question antitrust policies (see, for instance, Kwoka 2012), the general rise in industry concentration does not appear to raise troubling issues for antitrust enforcement at this point by itself.

But the rise in industry concentration raises policy concerns nevertheless. The growing productivity gap between the leading firms and the rest implies that the efficiency 
gains from IT are not being shared as widely as was the case with past technologies.

Increasingly, it seems, top performing firms utilize new technologies productively while their rivals cannot. Concentration appears to be rising because of "barriers to technology" if not actually barriers to entry.

But the impact is significant to society. Aggregate productivity growth has slowed because the rate at which new technology is diffused has slowed. The decline in productivity growth since the late 1990s has been of general concern. Some economists, such as Robert Gordon, argue that there has been a slowdown in the rate of innovation. However, the evidence noted here about the performance of top firms (e.g., Figure 2) suggests that there is no slowdown in their productivity growth. Instead, careful research decomposing the sources of productivity growth finds that the much of the slowdown can be attributed to the growing failure of productivity growth to spread to most firms (Decker et al. 2017). Moreover, the slowdown in diffusion affects wage inequality. Research also shows that more productive firms pay more and that a substantial part of the growth in wage inequality is associated with growing differences between firms.

A key goal of IP policy has been to promote the diffusion of new ideas. A key goal of antitrust policy has been to reduce barriers so that rivals can compete effectively. These goals have always been balanced against the objective of providing strong incentives to innovate and to encourage greater efficiency. But the evidence reviewed here shows that over the last 15 years or so, that balance has been lost. There has been too little diffusion of new knowledge leading to slower productivity growth and greater economic inequality.

Although IP and antitrust policies might not be the primary cause of the decline in diffusion, they should play a role in reversing the trend. The worry is that in some areas policy, too, has shifted against diffusion. To the extent that rising use of employee 
noncompete agreements limits the ability of technical employees to take their skills to new firms, diffusion is slowed. Similarly, for extensions of trade secrecy law to cover knowhow or the presumption of inevitable disclosure. Patents are required to disclose the technical information needed to "enable" the invention, but perhaps these requirements are ineffective, especially in IT fields. And if patents are not licensed, they become a barrier to diffusion. Perhaps some forms of compulsory licensing might overcome this problem. Moreover, machine learning technologies portend even greater difficulties encouraging diffusion in the future because use of these technologies requires not only skilled employees, but also access to critical large datasets.

Policy measures to improve the diffusion of knowledge might have the effect of reducing innovation incentives to some extent. There is often a tradeoff. However, over the last 15 or 30 years, the evidence suggests that innovation incentives have grown stronger while the rate of diffusion has slowed. Patenting rates are up dramatically as are rates of patent litigation; trade secret litigation and litigation over noncompete agreements are also up sharply. These data suggest that the incentives to obtain and enforce IP rights may have increased, although this evidence is hardly conclusive. The productivity of the top firms has accelerated as seen in Figure 2. Nevertheless, the net result has been that the spread of productive knowledge has been substantially restricted from what it was 15 years ago. Fixing this problem might require some lessening of innovation incentives. It is also a problem that involves multiple areas of IP and antitrust policy; the net economic effect of each cannot be properly evaluated in isolation from the overall effect on knowledge diffusion. The challenge both today and in the future for both IP and antitrust policy is to facilitate the diffusion of new technical knowledge and right now the trend seems to be in the wrong direction. 


\section{Reference}

Abowd, John M., John Haltiwanger, Julia Lane, Kevin L. McKinney, and Kristin Sandusky. Technology and the demand for skill: an analysis of within and between firm differences. No. w13043. National Bureau of Economic Research, 2007.

Andrews, Dan, Chiara Criscuolo, and Peter N. Gal. The Best versus the Rest: The Global Productivity Slowdown, Divergence across Firms and the Role of Public Policy. No. 5. OECD Publishing, 2016.

Autor, David, David Dorn, Lawrence F. Katz, Christina Patterson, and John Van Reenen. The Fall of the Labor Share and the Rise of Superstar Firms. No. 23396. National Bureau of Economic Research, Inc, 2017.

Barkai, Simcha. "Declining labor and capital shares." Stigler Center for the Study of the Economy and the State New Working Paper Series 2 (2016).

Berlingieri, Giuseppe, Patrick Blanchenay, and Chiara Criscuolo. "The great divergence." OECD working paper (2017).

Bessen, James. "Information Technology and Industry Concentration," Boston Univ. School of Law, Law and Economics Research Paper No. 17-41 (2018).

Calligaris, Sara, Chiara Criscuolo and Luca Marcolin, "Mark-ups in the digital era," OECD (2018).

Decker, Ryan A., John Haltiwanger, Ron S. Jarmin, and Javier Miranda. "Declining Dynamism, Allocative Efficiency, and the Productivity Slowdown." American Economic Review 107, no. 5 (2017): 322-26.

De Loecker, Jan, and Jan Eeckhout. The Rise of Market Power and the Macroeconomic Implications. No. w23687. National Bureau of Economic Research, 2017.

Demsetz, Harold. "Industry structure, market rivalry, and public policy." The Journal of Law and Economics 16, no. 1 (1973): 1-9.

Doms, Mark, Timothy Dunne, and Kenneth R. Troske. "Workers, wages, and technology." The Quarterly Journal of Economics (1997): 253-290.

Grullon, Gustavo, Yelena Larkin and Roni Michaely. "Are US Industries Becoming More Concentrated?" working paper (2017).

Gutiérrez, Germán and Thomas Philippon. "Declining Competition and Investment in the U.S.” NBER Working Paper (2017).

Hughes, Joseph P., and Loretta J. Mester. "Who said large banks don’t experience scale economies? Evidence from a risk-return-driven cost function." Journal of Financial Intermediation 22, no. 4 (2013): 559-585.

Kwoka Jr, John E. "Does Merger Control Work: A Retrospective on US Enforcement Actions and Merger Outcomes." Antitrust LJ 78 (2012): 619.

Peltzman, Sam. "The gains and losses from industrial concentration." The Journal of Law and Economics 20, no. 2 (1977): 229-263. 
Rognlie, Matthew. "Deciphering the fall and rise in the net capital share: accumulation or scarcity?." Brookings papers on economic activity 2015.1 (2016): 1-69.

Scherer, Frederic M. "The causes and consequences of rising industrial concentration." The Journal of Law and Economics 22, no. 1 (1979): 191-208. 
Figure 1. Operating Margins

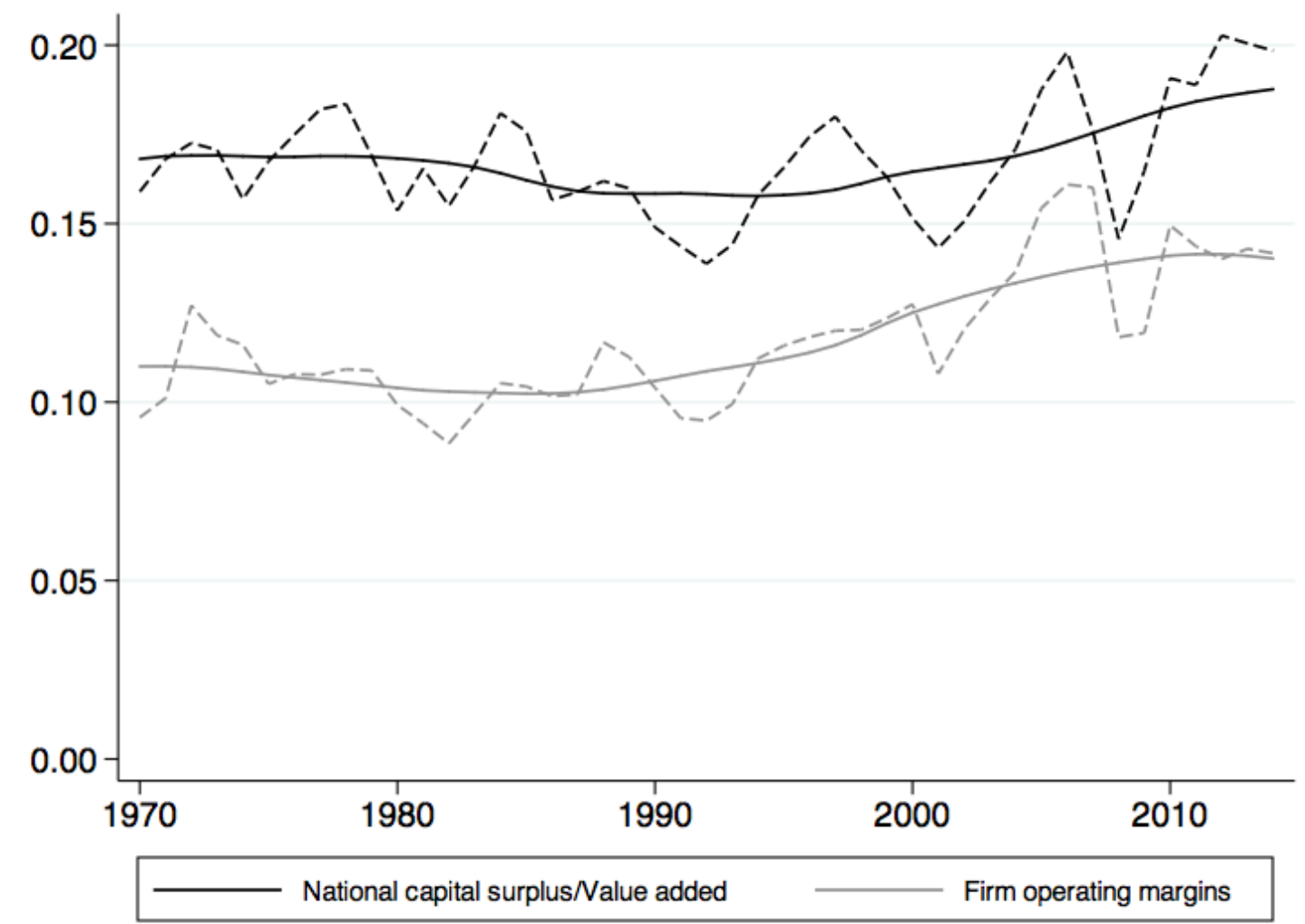


Figure 2. Labor Productivity Growth Among Publicly Listed Firms, US (Compustat)

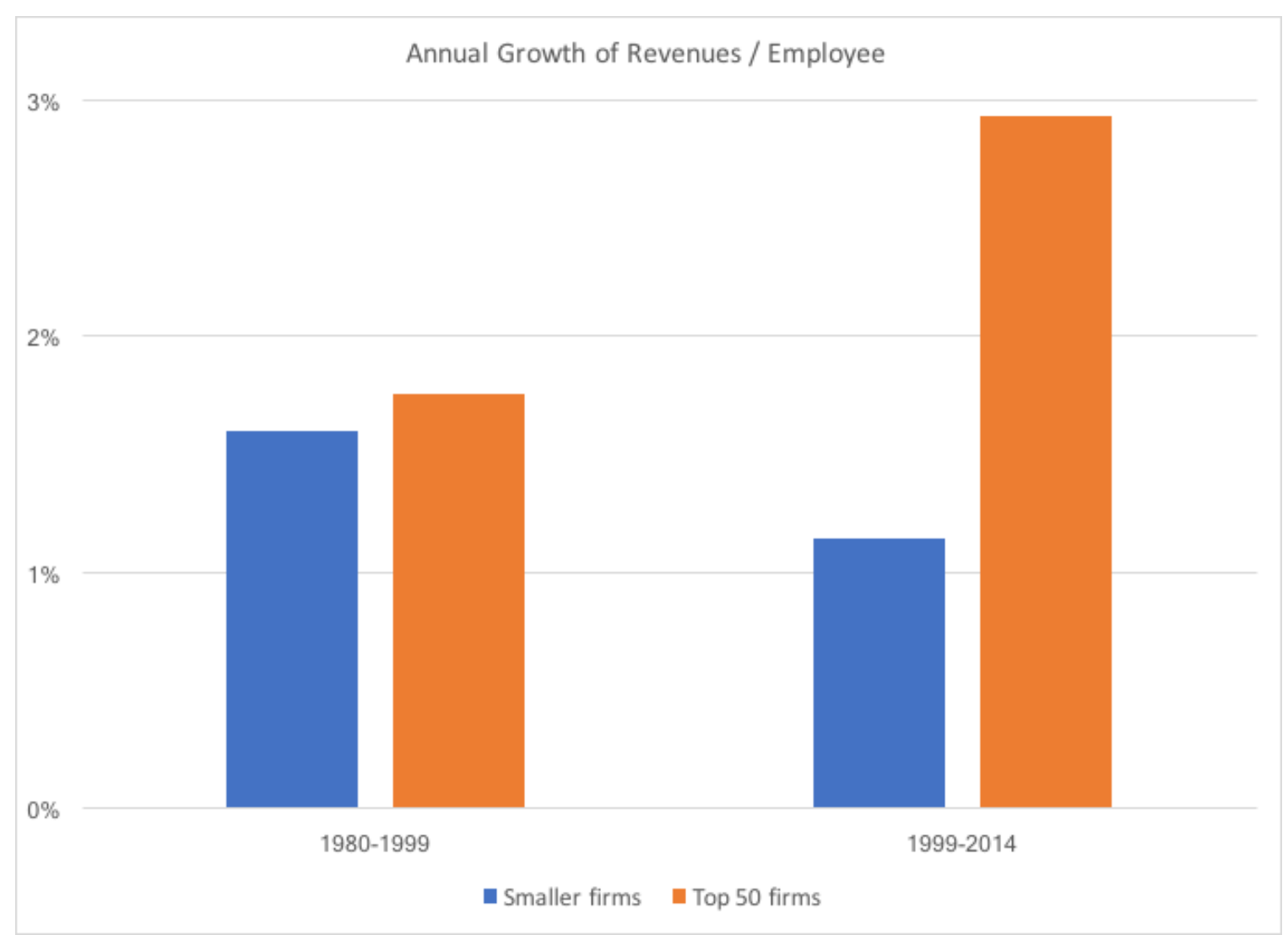

